\title{
KETELADANAN KEPEMIMPINAN YESUS DAN IMPLIKASINYA BAGI KEPEMIMPINAN GEREJA PADA MASA KINI
}

\author{
Katarina \& Krido Siswanto \\ Sekolah Tinggi Teologi Simpson \\ Jl. Agung No. 66, Krajan, Kel. Susukan, Kec. Ungaran Timur, Kab. Semarang, Jawa Tengah \\ Email: tatayuni76@gmail.com
}

\begin{abstract}
Katarina \& Krido Siswanto, Exemplary Leadership of Jesus and Its Implications for Church Leadership In Today. This paper is an analysis of the exemplary leadership of Jesus and its implications in the present. The author conducts literature research by looking at the principles of Jesus' leadership in the four Gospels, then finding the implications. From the results of the study, the Bible shows that Jesus is a figure who can be an example to his community and the example of his leadership is still relevant to Christian leadership today. The Bible shows that there are at least four areas of exemplary leadership of Jesus: the character of Jesus in leading, the spirituality of Jesus in leading, the management of Jesus in leading, and the ministry of Jesus in leading.
\end{abstract}

Keywords: Leadership, Jesus, the Bible

Abstrak: Katarina \& Krido Siswanto, Keteladanan Kepemimpinan Yesus dan Implikasinya Bagi Kepemimpinan Gereja Pada Masa Kini. Tulisan ini merupakan analisis tentang keteladanan kepemimpinan Yesus dan implikasinya pada masa kini. Penulis melakukan penelitian literatur dengan mencermati prinsip kepemimpinan Yesus dalam keempat Injil, kemudian menemukan implikasinya. Dari hasil penelitian, Alkitab menunjukkan bahwa Yesus adalah sosok yang dapat menjadi teladan bagi komunitas-Nya dan keteladanan kepemimpinan-Nya masih relevan dengan kepemimpinan Kristen pada masa kini. Alkitab menunjukkan paling tidak ada empat bidang keteladanan kepemimpinan Yesus, yaitu: karakter Yesus dalam memimpin, kerohanian Yesus dalam memimpin, manajemen Yesus dalam memimpin, dan pelayanan Yesus dalam memimpin.

Kata kunci: Kepemimpinan, Yesus, Alkitab.

\section{PENDAHULUAN}

Pemimpin Kristen sangat berbeda dengan pemimpin dunia, sebab pemimpin Kristen berpengaruh terhadap perkembangan suatu gereja atau pun komunitas Kristen. Oleh sebab itu, pemimpin Kristen dituntut untuk dapat menjalankan perannya dengan baik, agar tercipta kepemimpinan yang dapat memberi pengaruh. Seorang pemimpin Kristen dituntut untuk menyadari keberadaannya sebagai pemimpin dan motivasinya dalam memimpin. Ketika keberadaannya sebagai pemimpin dapat dijalankan dengan baik, maka kepemimpinan tersebut akan memberi dampak yang baik bagi gereja maupun komunitas Kristen. Namun dalam praktik di lapangan masih ditemukan pemimpin Kristen yang kurang menyadari panggilannya sebagai pemimpin.
Sebagai contoh, seorang gembala sidang yang memimpin gereja dituntut untuk menyadari bahwa kepemimpinan yang sedang dijalani dengan penuh tanggung jawab baik kepada manusia terlebih lagi kepada Tuhan. Peneliti mengamati ketika seorang gembala sidang kurang menyadari panggilannya, maka akan mempengaruhi motivasi dan fokus pelayanan, sehingga berdampak pada hasil pelayanannya. Lebih dari itu, gembala sidang merupakan hamba Tuhan dalam arti menyerahkan diri secara penuh waktu menjadi hamba Tuhan. Adapun tugas seorang hamba ialah melayani tuannya. Seorang hamba tidak dapat mengabdi kepada dua tuan (Mat. 6:24 dan Luk. 16:13). Memang memiliki pekerjaan sampingan bukanlah hal yang salah akan tetapi ketika hal tersebut mengganggu fokus pelayanan, maka akan mempengaruhi pelayanan menjadi tidak mak- 
simal karena gembala sidang harus membagi waktu antara mengatur pelayanan dan pekerjaan. Akan lebih baik, jika seorang gembala sidang lebih memfokuskan diri kepada kepemimpinan yang sedang berlangsung, sehingga penggembalaan di jemaat akan lebih efektif.

Perasaan atau sikap senioritas juga mempengaruhi efektif atau tidaknya sebuah kepemimpinan. Sikap senioritas akan sangat mempengaruhi perilaku seorang pemimpin yang akhirnya akan selalu merasa lebih dari yang lain. Apalagi memberi kepercayaan kepada orang muda yang belum memiliki pengalaman yang cukup dalam bidang tertentu. Hal ini perlu diperbaiki, karena sikap senioritas akan menimbulkan perpecahan dalam sebuah kepemimpinan. Kepemimpinan memiliki peranan yang sangat penting dalam kemajuan sebuah gereja (Objantoro, 2017, p. 123). Kemudian Mawikere (2018) menjelaskan bahwa kepemimpinan merupakan faktor yang tidak pernah mengenal kadaluarsa di dunia ini, sebab pemimpin-pemimpin adalah isu dari perubahan yang terjadi di dunia ini.

Mencermati berbagai persoalan yang terjadi terkait dengan kepemimpinan, maka Alkitab menampilkan Yesus sebagai seorang pemimpin bagi komunitasnnya yang dapat dijadikan teladan. Sebagaimana ditunjukkan dalam beberapa bagian Alkitab, Yesus adalah teladan bagi para murid-Nya bagaimana menjadi pemimpin. Oleh karena itu, penulis memandang perlu untuk menguraikan keteladanan kepemimpinan Yesus dan menemukan implikasinya bagi kepemimpinan masa kini. Memang telah ada berbagai uraian dalam beberapa buku tentang kepemimpinan Yesus, tetapi beberapa implikasinya perlu dikemukakan ulang sehingga dapat menjadi lebih relevan dengan konteks masa kini.

Rumusan masalah dalam karya ilmiah ini adalah bagaimana keteladanan kepemimpinan Yesus berdasarkan keempat Injil dan implikasinya pada masa kini? Adapun tujuan dalam penelitian ini adalah untuk menemukan keteladanan kepemimpinan Yesus berdasarkan keempat Injil dan implikasinya pada masa kini.

\section{METODE}

Metode yang digunakan dalam penelitian ini adalah metode literatur. Pendekatan tematis digunakan untuk memahami keteladanan kepemimpinan Yesus, kemudian melakukan sintesa dari berbagai sumber mengenai keteladanan Yesus dalam memimpin. Penulis kemudian melakukan analisis terhadap sumber-sumber yang terkait. Hasil analisis tersebut kemudian dipaparkan secara deskriptif, sehingga menjadi sebuah uraian yang rinci dan mendalam.

Hasil analisis terhadap keteladanan kepemimpinan Yesus juga dilihat implikasinya bagi kepemimpinan masa kini. Implikasi yang dikemukakan bersifat teoritis dan praktis, sehingga temuan dari penelitian ini dapat bermanfaat bagi pengembangan keilmuan dalam kepemimpinan Kristen dan praktik kepemimpinan Kristen di Indonesia.

\section{HASIL DAN PEMBAHASAN}

\section{Definisi dan Pengertian Kepemimpinan Yesus}

Jahenos Saragih (2009, p. 148) memaparkan

"Kepemimpinan (leadership) adalah cara atau teknik pimpinan atau manejer untuk mengarahkan dan menyuruh orang lain agar mau mengerjakan apa yang ditugaskan." Kemudian Octavianus (1988, p. 227) menuliskan bahwa "Meneladani kepemimpinan Yesus Kristus, berarti memanifestasikan kehadiran-Nya di bumi, untuk memperbaharui hidup dan memberikan hidup yang kekal kepada manusia." Tomatala (1997, p. 43), demikian:

Kepemimpian Kristen ialah suatu proses terencana yang dinamis dalam konteks pelayanan Kristen (yang menyangkut faktor waktu, tempat, dan situasi khusus) yang di dalamnya oleh campur tangan Allah, Ia memanggil bagi diriNya seorang pemimpin (dengan kapasitas penuh) untuk memimpin umat-Nya (dalam pengelompokan diri sebagai suatu institusi/organisasi) guna mencapai tujuan Allah (yang membawa keuntungan bagi pemimpin, bawahan, dan lingkungan hidup) bagi dan melalui umat-Nya untuk kejayaan Kerajaan-Nya.

Dari uraian di atas tampak bahwa kepemimpinan Yesus menjadi teladan dan memberi pengaruh yang 
baik bagi orang yang dipimpin. Sementara Suwu (2016, p. 31) menjelaskan tentang kepemimpinan rohani atau kepemimpinan Kristen adalah, "Suatu proses yang dinamis untuk melaksanakan pelayanan menyeluruh terhadap umat Allah menuju pada kedewasaan rohani, dan menolong setiap warga gereja melaksanakan Amanat Agung." Dari pernyataan tersebut membuktikan bahwa kepemimpinan Kristen ialah suatu proses mengabdikan diri atau pelayanan. Alkitab menjelaskan kehadiran Yesus "Karena Anak Manusia juga datang bukan untuk dilayani, melainkan untuk melayani dan untuk memberikan nyawaNya menjadi tebusan bagi banyak orang." (Mrk. 10: 45, LAI).

\section{Ciri-ciri Kepemimpinan Yesus}

Jahenos (2009, p. 147) menjelaskan bahwa dalam Perjanjian Baru kata pemimpin berasal dari kata Yunani hadegos yang memiliki arti memimpin, penuntun dan pembimbing, kemudian dalam bentuk kata kerja dipakai kata hadegein yang artinya menuntun dan membimbing. Jadi pemimpin dalam Perjanjian Baru dapat dimengerti sebagai seorang yang berdiri dibarisan depan, yang menuntun serta membimbing orang yang dipimpin atau jemaat.

Ciri-ciri kepemimpinan Yesus ialah mempengaruhi dan menularkan visi serta misi kepada para murid dan pengikut-Nya, sehingga dengan mudah para murid dan pengikut-Nya terpengaruh oleh perkataan-Nya. Yesus tidak menjadi seseorang pemimpin yang otoriter, melainkan memimpin dengan kasih, kerendahan hati, integritas serta berhati hamba. Kepemimpinan Yesus berbasis pelayanan, sehingga tidak ada hal yang bersifat menguntungkan pribadi. Henry (2011, p. 238) memaparkan bahwa umumnya kekuasaan disalahgunakan dalam dunia ini. Kepemimpinan masa kini cenderung dalam ambisi pribadi dan organisasi, sehingga keteladanan Yesus dalam memimpin tidak menjadi prinsip dasar dalam kepemimpinan. Pemimpin seharusnya dapat mengayomi orang yang dipimpin dengan baik, melindungi, dan memberi kesejahteraan bukan memanfaatkan kekuasaan, kemewahan dan kemegahan.

\section{Keteladanan Kepemimpinan Yesus}

Ada beberapa teladan kepemimpinan Yesus, antara lain:

\section{Karakter Yesus Dalam Memimpin}

Pada sisi karakter Yesus memberikan teladan dalam beberapa hal:

Kasih

Dalam pelayanan dan pengajaran Yesus lebih menekankan mengenai kasih. Dalam Injil Matius 22:37-39 (LAI), kasih sangat jelas dituliskan demikian:

Jawab Yesus kepadanya: Kasihilah Tuhan Allahmu, dengan segenap hatimu dan dengan segenap jiwamu dan dengan segenap akal budimu. Itulah hukum yang terutama dan yang pertama. Dan hukum yang kedua, yang sama dengan itu, ialah: kasihilah sesamamu manusia seperti dirimu sendiri.

Sedangkan Robinson (2014, p. 91) mengungkapkan bahwa, kasih agape mendorong seorang pemimpin untuk mengusahakan yang terbaik bagi orang lain, bukan hanya untuk menguntungkan diri sendiri. Ungkapan Robinson menyatakan bahwa kehidupan seorang pemimpin diperlukan kasih yang berasal dari Allah ialah kasih agape. Menurut Robinson (2014, p. 89) "Kasih agape adalah wujud kerelaan kita yang menempatkan kepentingan orang lain di atas kepentingan kita." Sementara itu, Yeakley (2013, p. 41) memaparkan dalam bukunya bahwa "Kasih agape (kata benda dalam bahasa Yunani) adalah kualitas karakter dasar dari seorang pemimpin rohani." Dari pernyataan tersebut membuktikan bahwa, kepemimpinan rohani sangat memerlukan kasih sebagai landasan di dalam memimpin. Seorang pemimpin yang memiliki kasih akan berusaha memberikan yang terbaik bagi orang yang dipimpin. Swindoll (1985, p. 162) menjelaskan dalam bukunya mengenai "Kasih sejati mengatakan kebenaran. Orang yang sungguhsungguh menyatakan kasih sejati, membuktikan dengan kata-katanya, yang penuh dengan kesungguhan dan ketulusan." Seorang pemimpin yang memiliki kasih sejati, akan memiliki kedewasaan dalam mengambil keputusan. 
Injil Markus 10:42-43 (LAI) mencatat pernyataan Yesus mengenai kasih:

Kamu tahu, bahwa mereka yang disebut pemerintah bangsa-bangsa memerintah rakyatnya dengan tangan besi, dan pembesar-pembesarnya menjalankan kuasanya dengan keras atas mereka. Tidaklah demikian di antara kamu. Barang siapa ingin menjadi besar di antara kamu, hendaklah ia menjadi pelayanmu.

Dalam konteks Injil Markus 10:42-43, pengajaran yang diberikan Yesus kepada pemimpin rohani ialah untuk memimpin dengan kasih dan rendah hati bukan dengan otoriter. Henry (2011, p. 238-239) menjelaskan bahwa dalam peristiwa yang terkait dengan cerita dalam Markus 10:42-43 ada kemarahan murid-murid lain terkait ambisi Yakobus dan Yohanes, tetapi dalam peristiwa tersebut tampak pula ambisi murid-murid yang lain. Kesempatan tersebut menurut Henry, digunakan Yesus untuk memberikan sebuah contoh bagi para murid mengenai kasih dan kerendahan hati.

Hal yang serupa dicatat dalam Injil Yohanes 13:34-35(LAI) demikian

Aku memberitahukan perintah baru kepada kamu, yaitu supaya kamu saling mengasihi. Dengan demikian semua orang akan tahu, bahwa kamu adalah murid-murid-Ku, yaitu jikalau kamu saling mengasihi.

Henry (2010, p. 970) menyebutkan bahwa pada peristiwa yang dicatat dalam Injil Yohanes 13:34-35, Yesus memberikan pada murid mengenai sebuah tugas agung untuk saling mengasihi. Dalam bagian lain tafsirannya, Henry (2010, p. 974) menyebutkan bahwa bila seorang unggul dalam mengasihi, itu merupakan sebuah kehormatan besar. Dengan demikian jelas bahwa untuk menjadi pemimpin yang baik maka memiliki kasih sangatlah penting.

\section{Kerendahan Hati}

Salah satu musuh dalam kepemimpinan ialah kesombongan, kesombongan akan membawa kepada kehancuran. Sebagaimana Alkitab memaparkan, "Belajarlah kepada-Ku, karena Aku lemah lembut dan rendah hati dan kamu akan mendapatkan kelegaan bagi jiwamu." (Mat. 11:29b, LAI). Sanders
(1962, p. 108) dalam bukunya memaparkan bahwa ungkapan berbahagialah orang yang lemah lembut, karena mereka akan memiliki bumi menunjukkan bahwa Yesus datang ke dunia, meninggalkan zona nyaman-Nya demi sebuah misi besar yaitu menyelamatkan umat manusia, diperlukan kerendahan hati untuk melakukan itu semua.

Yeakley (2013, p. 102) mengutarakan arti dari kerendahan hati, "Kerendahan hati adalah kualitas merupakan akar dari hati hamba." Dari pendapat di atas, kerendahan hati akan membentuk suatu karakter seseorang pemimpin. Murray (2001, p. 73) mengemukakan bahwa:

Hal yang terpenting dalam kepribadian Yesus, yang terutama diusahakan-Nya agar memberi kesan yang dalam pada diri murid-murid-Nya ialah kerendahan hati. Penjelmaan-Nya dan penebusan-Nya berakar pada kerendahan hatiNya.

Dari pernyataan tersebut Yesus menghendaki para pemimpin rohani meneladani kerendahan hati-Nya. Kerendahan hati dapat menyentuh hati orang lain, seperti yang Yesus lakukan saat Ia membasuh kaki para murid (Yoh. 13:3-5).

Kerendahan hati berawal dari perkara-perkara yang kecil. Brake $(2014$, p. 32) menjelaskan dalam bukunya bahwa Kerajaan Surga merupakan milik mereka yang rendah hati. Pernyataan tersebut dapat menginspirasi para pemimpin untuk memiliki kerendahan hati dalam memimpin. Kerendahan hati akan membentuk suatu pribadi yang tangguh, dan akan menyingkirkan kesombongan dan ambisi pribadi. Untuk dapat mencapai tujuan didalam kepemimpinan seorang pemimpin hendaknya memiliki karakter rendah hati dibuktikan dengan mau menerima kritikan, masukan, serta saran-saran dari orang yang dipimpin.

Integritas

Menurut Yeakley (2013, p. 66), "Padanan kata integritas dalam bahasa Yunani adalah alethes, artinya 'jujur' ketika mendeskripsikan seseorang." Yeakley (2013, p. 66), juga menjelaskan bahwa dalam bahasa Inggris, kata integritas berasal kata "in- 
tegrity” yang berarti “... Keterikatan yang kuat terhadap aturan yang khususnya terdiri dari nilai-nilai moral, kejujuran karakter dan prinsip moral yang baik, serta kualitas kejujuran." Selanjutnya Tanihardjo (2015, p. 38) menjelaskan pengertian integritas adalah "Jati diri seseorang sebagai sesuatu yang utuh dan tidak terpisahkan, di dalamnya terdapat unsur ketulusan hati dan dapat dipercaya." Dari pernyataan tersebut membuktikan bahwa seseorang pemimpin harus memiliki integritas, sehingga dengan integritas seseorang dapat dipercayai dalam perkataan dan tindakannya.

Matius 22:15-22, Markus 12:13-17, dan Lukas 20:20-26 menjelaskan bahwa Yesus pernah dicobai oleh orang-orang Farisi, Yesus tahu bahwa maksud orang-orang Farisi adalah jahat. Tetapi dengan kasih-Nya yang besar kepada umat manusia, Yesus menjawab dengan bijaksana. Yesus telah membuktikan bahwa Ia tetap memiliki reputasi dan pribadi yang memiliki integritas. Yesus tetap konsisten dengan perkataan-Nya dan pengajaran-Nya "Jika ya, hendaklah kamu katakan: ya, jika tidak, hendaklah kamu katakan: tidak. Apa yang lebih dari pada itu berasal dari si jahat." (Mat. 5:37, LAI). Yesus dapat membangun relasi dengan Allah Bapa, murid-muridNya. Tanpa integritas seorang pemimpin tidak akan dapat memimpin dengan baik, bahkan akan ditinggalkan oleh pengikutnya. Manullang (2007, p. 75) memaparkan pengertian integritas dalam bukunya "Integritas merupakan fondasi dalam pelayanan, sehingga ketika badai pencobaan menerjang pelayanannya, orang tersebut akan tetap mampu berdiri teguh." Dengan demikian integritas akan menjadi dasar seseorang pemimpin untuk memiliki komitmen dalam pelayanan.

\section{Berhati Hamba}

Blanchard dan Hodges (2006, p. 49) menjelaskan bahwa "Kendala terbesar untuk memimpin seperti Yesus adalah hati yang dimotivasi oleh kepentingan pribadi." Sementara itu Tong dan Setiawani (2003, p. 99) menjelaskan bahwa:
Pada saat kita merendahkan diri, bukan berarti kita menghilangkan konsep ideal yang tinggi. Ide yang tinggi dan sempurna harus terus kita tuntut tanpa mengendur. Ide ideal itu adalah contoh bagaimana Kristus hidup di dunia ini di hadapan Allah Bapa dan di hadapan manusia.

Dari pernyataan di atas menjelaskan seseorang pemimpin yang memiliki kerendahan hati dengan sendirinya akan berhati hamba.

Kepemimpinan dunia berbeda dengan kepemimpinan rohani, adapun hal yang membedakannya ialah seorang pemimpin rohani harus benar-benar menyadari bahwa keberadaan kepemimpinan yang berlangsung atas rencana Tuhan bukan ambisi pribadi. Murray (2001, p. 32) memaparkan bahwa “... pekerjaan yang harus dilakukan Yesus bagi orangorang berdosa sehingga untuk itu Ia harus memberikan diri-Nya sendiri." Dari pernyataan di atas membuktikan bahwa Yesus mengabdikan Diri kepada Bapa, serta memberi Diri untuk menjadi penebus. Melalui pengorbanan Yesus ada pembaharuan dan keselamatan. Yesus membasuh kaki murid-muridNya (Yoh. 13:1-20), pencobaan di padang gurun (Mat. 4:1-11, Mrk. 1:12-13, dan Luk. 4:1-13) menjadi bukti bahwa, Yesus memiliki hati hamba yang merendahkan diri untuk membasuh kaki muridmurid-Nya dan melaksanakan kehendak Bapa melalui pencobaan di padang gurun.

\section{Kerohanian Yesus Dalam Memimpin}

\section{Tekun Dalam Berdoa}

Abineno (1994, p. 1) dalam bukunya memaparkan bahwa "Dalam hidup dan pekerjaan Yesus doa menempati tempat yang terpenting." Abineno (1994, p. 8) Ia kembali memaparkan bahwa “... sebagai orang Yahudi Yesus mengikuti kebiasaan bangsa-Nya yang berdoa tiga kali sehari, yaitu pada waktu pagi, pada waktu siang, dan pada waktu petang atau malam." Hal yang membedakan Yesus dengan orang Yahudi pada umumnya ialah waktu dan tempat, Alkitab mencatat Yesus berdoa pada pagipagi sekali dan di tempat yang sunyi (Mrk. 1:35, Mat. 21:28, dan Luk. 22:40). Dari waktu dan tempat 
tersebut membuktikan bahwa Yesus ingin mempersiapkan diri dengan baik dalam hal berdoa. Bukan serupa dengan orang-orang munafik:

Dan apabila kamu berdoa, janganlah berdoa seperti orang munafik. Mereka suka mengucapkan doanya dengan berdiri dalam rumah-rumah ibadat dan pada tikungan-tikungan jalan raya, supaya mereka dilihat orang. Aku berkata kepadamu: Sesungguhnya mereka sudah mendapat upahnya. (Mat. 6:5, LAI).

Yesus ingin mengajarkan kepada para murid-Nya, serta pengikut-Nya untuk bersungguh-sungguh dalam hal berdoa (Mat. 6:9-11 dan Yoh. 17:9). Hal ini membuktikan bahwa Yesus ialah sosok pemimpin yang mengutamakan doa.

Whitney (2007, p. 72) memaparkan dalam bukunya bahwa “... dari perkataan Tuhan Yesus, seluruh isi kitab Perjanjian Baru tak salah lagi menyingkapkan kehendak Allah bagi kita, yaitu agar kita berdoa." Yesus telah memberi teladan yang baik dalam hal berdoa, sehingga didalam kepemimpinanNya berdampak positif. Sanders (1979, p. 18) menjelaskan bahwa "Wewenang dan kepemimpinan rohani diperoleh bukan dengan usaha memajukan diri, melainkan banyak berdoa, dan air mata." Yesus membuktikan bahwa didalam kepemimpinan sangat memerlukan doa, ketika Yesus berada di taman Getsemani "Ia sangat ketakutan dan makin bersungguhsungguh berdoa. Peluhnya sampai seperti titik darah yang bertetesan ke tanah." (Luk. 22:44, LAI). Wiersbe dan Wiersbe (2011, p. 99) menjelaskan bahwa "Kesungguhan firman Allah dan doa akan memberi keseimbangan pada hidup dan pelayanan kita." Keseimbangan seorang pemimpin ditentukan dari kesungguhan dan ketekunan dalam hal berdoa, karena doa merupakan bentuk penyerahan diri dibawah otoritas Allah.

Tong (2001, p. 76) menjelaskan "Doa merupakan pernyataan keterbatasan diri kita, ketidakmampuan kita, yang menyebabkan kita datang kepada Dia." Jadi, berdoa merupakan ungkapan hati seseorang untuk memohon pertolongan dan pengakuan bahwa Allah satu-satunya sumber kehidupan. Berdoa berarti merendahkan diri di bawah kuasa Tuhan.
Membaca Kitab Suci

Selain bertekun dalam doa, Yesus melandasi kepemimpinan-Nya dengan membaca Kitab Suci. Berdasarkan Matius 4:1-9 yang mencatat dari cerita pencobaan di padang gurun (Mat. 4:1-9, Mrk. 1:12, Luk. 4:1-13), Yesus membuktikan bahwa Ia senang dan gemar membaca Kitab Suci. Morris (2016, p. 82) menafsirkan dalam tafsiran Injil Matius pada ayat 10 “... seperti halnya kedua pencobaan sebelumnya, Yesus menolak godaan ini dengan tegas dan dengan mengutip ayat Kitab Suci." Yesus menjawab orang-orang Farisi, ketika melihat murid-murid-Nya memetik gandum pada hari sabat "atau tidakkah kamu baca dalam Kitab Taurat, bahwa pada hari sabat, imam-imam melanggar hukum sabat di dalam Bait Allah, namun tidak bersalah?." (Mat. 12:5, LAI). Hal yang sama ditafsirkan oleh Morris (2016, p. 311) dalam bukunya bahwa "Sekali lagi Yesus mengutip Kitab Suci dan bertanya "tidakkah kamu baca?."

Selain itu Boice (2015, p. 579) memaparkan bahwa "Yesus memulai pelayanan-Nya ketika Ia membaca dari gulungan kitab Yesaya di sinagoge di Nazaret." Dari pernyataan di atas membuktikan bahwa Yesus tekun dalam membaca Kitab Suci, sehingga Ia dapat mengutip dan memahami semua bagian dari Kitab Suci. Oleh karena itu, seseorang pemimpin harus menyediakan waktu dalam membaca dan merenungkan Kitab Suci, sebagai pedoman kepemimpinannya. Selain sebagai pedoman, Kitab Suci menjadi landasan seseorang pemimpin dalam mengambilan keputusan, arahan dalam bertindak serta acuan dalam melaksananakan tugas kepemimpinan.

\section{Setia dalam Memberitakan Injil}

Memberitakan Injil adalah tanggung jawab semua orang percaya. Halim (2003, p. 25) memaparkan dalam bukunya bahwa

Penginjilan berasal kata dari bahasa Yunani yakni Euangelion yang berarti Good News atau kabar baik. The Gospel, yang berarti berita keselamatan, berita pengampunan, berita perdamaian, dan berita pengudusan bagi orang berdosa. 
Matius 28:19-20, Markus 16:19-20, Lukas 24:46-49 dan Yohanes 20:30-31 adalah landasan dari penginjilan, penginjilan merupakan kehendak Allah dan mutlak dari Allah.

Dalam Matius 4:23 dituliskan bahwa Yesus pun berkeliling di seluruh Galilea, Ia kemudian mengajar dalam rumah-rumah ibadat lalu memberitakan Injil Kerajaan Allah serta melenyapkan segala penyakit dan kelemahan di antara bangsa itu. Selain dikenal sebagai Guru Agung, Yesus juga giat dalam memberitakan Injil. Yesus yang sangat antusias dalam memberitakan Injil menjadi teladan bagi para pemimpin, bahwa dalam memimpin tidak hanya sebatas memimpin melainkan memperhatikan jiwa atau keselamatan yang dipimpin. Nee (2000, p. 97) memaparkan dalam bukunya bahwa memberitakan Injil merupakan mengutarakan kebenaran karena kasih, sehingga menjadi seorang pemimpin hendaknya memenuhi kebutuhan jasmani dan rohani seperti Yesus.

\section{Manajemen Yesus Dalam Memimpin}

\section{Mendelegasikan Tugas}

Patterson (2006, p. 213) menyatakan bahwa, "Pendelegasian berasal dari kata delegasi, ialah suatu pemberian wewenang atau kekuasaan serta tanggung jawab kepada orang lain.” Jadi, tugas didelegasikan kepada orang yang benar-benar dapat bertanggungjawab. Yesus mendelegasikan tugas kepada kedua belas rasul. Yesus menetapkan dua belas orang untuk menyertai Dia dan untuk diutus-Nya memberitakan Injil (Mat. 10:1-4, Mrk. 3:13-19, Luk. 6:12-16, dan Yoh. 35-51). Sementara Yesus memberi kuasa kepada kedua belas rasul untuk mengusir roh-roh jahat. Dari kisah dipilihnya kedua belas rasul tersebut merupakan sebuah gambaran bahwa Yesus mendelegasikan tugas-Nya.

Edgar Walz (2004, p. 95) menjelaskan dalam bukunya bahwa "Pendelegasian yang efektif memerlukan tiga unsur yaitu penyerahan tugas, pemberian wewenang, dan penciptaan kewajiban." Darmawan (2017) juga menekankan bahwa dalam pen- delegasian perlu sikap percaya dan hal itu tampak dalam kehidupan Yesus sebagai pemimpin. Menurut ungkapan di atas mendelegasiakan berarti menyerahkan tugas sepenuhnya kepada penerima delegasi, penerima delegasi mendapatkan wewenang sehingga penerima delegasi memiliki kewajiban untuk melakukan tugas yang telah diberikan.

Soekahar (1988, p. 68) menjelaskan dalam bukunya bahwa "Pada prinsipnya, kepemimpinan Rohani yang baik tidak dapat terjadi secara tiba-tiba dengan sendirinya tanpa mempersiapkan orangorang tertentu dalam waktu yang cukup lama." Jadi, untuk menentukan penerima delegasi harus dipersiapkan dengan baik. Mendelegasikan tugas berarti pemberi delegasi mewariskan kemampuan yang dimiliki kepada penerima delegasi. France (1998, p. 49) memaparkan bahwa "Pemilihan kedua belas murid oleh Yesus merupakan salah satu keputusan-Nya yang paling penting. Ia berdoa sepanjang malam sebelum pemilihan; hal itu menunjukkan betapa penting pemilihan itu bagi-Nya (Luk 6:12-13)." Muridmurid yang telah dipilih kemudian dilatih oleh Yesus dengan mencurahkan banyak tenaga dan perhatian. Setelah melakukan pemilihan kedua belas rasul, Yesus juga mengarahkan para murid untuk memiliki misi. France (1998, p. 50) juga menjelaskan bahwa "Misi mereka pada hakikatnya merupakan perluasan pelayanan Yesus. Pemberitaan-Nya dipusatkan pada Kabar Baik bahwa kerajaan Allah." Dalam menjalankan misi Bapa, Yesus mengarahkan para murid untuk terlibat dalam pemberitaan Kabar Baik. Pemimpin yang baik pemimpin yang mengarahkan, membimbing serta menuntun pengikutnya untuk mencapai tujuan.

\section{Mengevaluasi Para murid}

Thomssoyan (2011, p. 74) memaparkan bahwa "Evaluasi merupakan tindak terakhir yang dilakukan dalam keseluruhan tindakan dan pelaksanaan pola kepemimpinan yang ada." Yesus memberi waktu khusus untuk mendengar dan mengevaluasi tugas para murid (Mrk. 10:30-32 dan Luk. 9:10-11). Menurut Coleman (1963, p. 70), "Ini merupakan 
strategi Yesus dalam seluruh pelayanan-Nya. Apabila Ia meninjau kembali pengalaman mereka, Ia menunjukan cara yang praktis untuk diterapkan dalam kehidupan." Dalam kepemimpinan Yesus ada kerja sama (Mat. 15:32-39 dan Mrk. 8:1-10) untuk merencanakan program-program, dan Yesus pun berhasil mengarahkan para murid dan pengikut-Nya.

\section{Pelayanan Yesus Dalam Memimpin}

\section{Melayani Banyak Orang}

Coleman (1963, p. 30) menjelaskan dalam bukunya:

Pada waktu Ia berbicara dengan orang banyak yang mengerumuni Dia, atau dengan ahli-ahli Taurat dan orang-orang Farisi yang berusaha menjerat Dia, atau dengan orang-orang pengemis di pinggir jalan, murid-murid-Nya berada di dekat Dia untuk ikut memperhatikan serta mendengar ajaran-Nya.

Pelayanan merupakan dasar kepemimpinan Yesus, sehingga dalam kepemimpinan-Nya lebih banyak waktu digunakan-Nya untuk bersama-sama dengan para rasul dan orang banyak. Yesus memberi makan lima ribu orang (Mat. 14:13-21, Mrk. 6:30-44, Luk. 9:10-17, dan Yoh. 6:1-15) menunjukan bahwa Yesus peduli akan keadaan orang banyak. Keadaan jasmani Yesus sudah pelihara terlebih keselamatan jiwa umat manusia. Kepemimpinan Yesus yang melayani terbukti ketika Yesus peduli dengan persoalan banyak orang; orang sakit disembuhkan (Mat. 4:24 dan Luk. 6:17-19), orang buta dicelikkan orang lumpuh berjalan (Mrk. 2:1-12), serta orang mati dibangkitkan (Luk. 7:11-17). Yesus memimpin dengan penuh kasih, sehingga ia tetap mengasihi orang berdosa dan menyembuhkan orang yang terluka, seperti kisah perempuan yang berzinah (Yoh. 8:1-11).

\section{Memberdayakan Murid-murid}

Pola kepemimpinan yang dimiliki Yesus memang sederhana. Berdasarkan Matius 4:19 tampak jika Yesus memahami konteks lawan bicaraNya, sehingga dengan sengaja Yesus memberi sebuah tawaran, sehingga Simon dan Andreas pun mengikuti Yesus. Yesus mengharapkan para pemimpin baru atau para murid yang telah dipilih-Nya, dapat melayani. Selain mengajar para murid Yesus juga membimbing serta melatih para murid melalui setiap kejadian yang terjadi.

Henrichsen (1974, p. 91) memaparkan dalam bukunya "Seorang pelatih hanya dapat membantu perkembangan seseorang dalam dua bidang: (1) pengadaan waktu, dan (2) pengadaan kesempatan untuk belajar." Yesus melatih para murid-Nya dengan meluangkan waktu, memberi kesempatan kepada para murid untuk belajar, serta memberi kuasa kepada para murid (Mat. 10:1, Luk. 9:1, dan Yoh. 3: 27). Myron Rush (1993, p. 164) menjelaskan dalam bukunya bahwa "Para pemimpin harus sanggup melatih para pengikut dalam hal menerapkan kebenaran secara praktis." Yesus memberdayakan para murid dengan cara membimbing, melatih, serta ikut melibatkan diri dalam persoalan yang dihadapi para murid. Moore (1981, p. 33) menjelaskan bahwa "Pemuridan merupakan suatu cara yang tepat untuk melipatgandakan pemimpin-pemimpin yang mau melaksanakan penginjilan dan pemuridan." Yesus telah memberdayakan para murid dengan baik dibuktikan dengan sebagian dari para murid-Nya memiliki pengikut, dan telah memimpin dengan baik, seperti Yohanes pembaptis dan Petrus.

\section{Menjadi Teladan}

Stalker (1991, p. 126) menjelaskan tentang kepemimpinan Yesus demikian

Pengaruhnya dalam dunia mutakhir membuktikan betapa agungnya Dia dulu. Pengaruh-Nya meliputi kehidupan manusia dan membuatnya berkembang dengan semangat rohani. Kualitas pengaruh-Nya lebih luar biasa dari kuantitasnya.

Kebersamaan Yesus dengan murid-murid-Nya selama tiga setengah tahun, mulai dari Yesus dibaptis oleh Yohanes sampai pada kenaikan-Nya ke surga. Yesus dapat menjadi teladan dalam berapa hal berikut: Pertama, berdoa (Mat. 26:36, Mrk. 14:32, Luk. 22:41-42, dan Yoh. 17:9). Kedua, mengasihi. Yesus sangat mengasihi orang-orang berdosa (Mat. 9:10, 
Mrk. 5:21, Luk. 8:40-46, dan Yoh. 3:16). Kedatangan-Nya ke dunia merupakan teladan yang Yesus berikan bagi manusia. Yohanes 3:16 menunjukkan bahwa Yesus datang ke dunia karena kasih Allah yang besar, dan kasih kepada manusia menjadi tampak dalam seluruh pelayanan yang Yesus lakukan.

Dengan teladan yang Yesus berikan, Ia kemudian menjadi pemimpin yang berkesan bagi banyak orang terbukti dari banyaknya orang yang kemudian mengikuti-Nya. Yesuslah satu-satunya pemimpin yang memberi teladan dan dapat diteladani, karena Yesus memimpin dengan penuh hikmat.

\section{Implikasi Bagi Kepemimpinan Gereja Pada Masa Kini}

Secara teoritis, nilai-nilai kepemimpinan Yesus dapat diimplikasikan bagi kepemimpinan gereja pada masa kini. Berikut beberapa implikasi teoritisnya:

\section{Berkarakter Seperti Yesus}

Bagi pemimpin gereja pada masa kini, dituntut untuk memiliki pokok pengajaran yang membawa orang yang dipimpin kepada pertobatan. Jadi, seseorang pemimpin Kristen pada masa kini harus mempunyai prinsip dalam kepemimpinan yakni membebaskan dan menggubah orang yang dipimpin dari belenggu dosa dan membawa kepada keselamatan kekal, sebagaimana yang tergambar dalam karakter Yesus. Price (1975, p. 131) menjelaskan bahwa

Yesus berkata bahwa Ia datang untuk memerdekakan orang-orang yang terbelenggu. Kehidupan baru merupakan pokok pengajaran-Nya. Belenggu dosa harus dipatahkan dan jiwa harus dibebaskan. Pembebasan dan pengubahan hidup menduduki tempat yang terutama dalam pekerjaan-Nya.

Riggs (1978, p. 53) memaparkan dalam bukunya bahwa "Kasih karunia Allah dinyatakan melalui hidup seorang pendeta, maka itu dinyatakan dalam banyak cara pula." Selain memiliki kasih seseorang pemimpin Kristen harus memiliki kerendahan hati, sebagaimana teladan yang Yesus berikan, dimana Ia adalah sosok pemimpin yang rendah hati. Dari kerendahan hati terpancar sikap peka terhadap kebutuhan orang lain serta kemauan untuk menolong, yang pada akhirnya ada kepedulian dalam diri seseorang pemimpin Kristen.

\section{Memiliki Spiritualitas Kepemimpinan yang Baik}

Dari hasil di atas jelas bahwa Yesus adalah pemimpin yang memiliki spiritualitas yang baik. Memiliki spiritualitas kepemimpinan yang baik dibuktikan dengan ada waktu pribadi untuk berdoa, ketekunan untuk mempelajari Kitab Suci, serta setia dalam pekabaran Injil. Thomas (2000, p. 137) menjelaskan dalam bukunya

Yesus Kristus adalah segala sesuatu yang kita perlu ketahui tentang Allah, dan Yesus Kristus merupakan segala sesuatu yang kita perlu ketahui tentang manusia, dan jika kita "hidup dalam negeri itu" berarti menikmati mutu kehidupan yang hanya mungkin dijalankan jika kita mengizinkan Dia untuk menjalankan kehidupan-Nya di dalam kehidupan kita.

Seperti yang ditulis oleh Riggs (1978, p. 41) dalam bukunya "Waktu yang paling menyenangkan untuk berdoa dan menelaah Alkitab bagi seorang pendeta adalah di pagi hari." Apa yang dikemukakan oleh Riggs tampak dalam kehidupan Yesus, di mana Ia mengambil waktu khusus untuk berdoa.

Sebagai bentuk meneladani Yesus, seorang pemimpin Kristen harus meneladai kehidupan Yesus yang memiliki waktu khusus untuk berdoa, membaca Kitab Suci serta dengan setia memberitakan Injil. Dengan demikian kehidupan kerohanian seorang pemimpin harus dapat memahami keilahian dan kemanusiaan Yesus, serta menyerahkan kehidupan untuk dikuasai oleh kehendak-Nya.

\section{Kemampuan Manajemen dalam Memimpin}

Temuan terkait keteladanan kepemimpinan Yesus menunjukkan bahwa Yesus adalah pemimpin yang memiliki kemampuan manajemen. Iskandar (2008, p. 50) memaparkan bahwa manajemen Kristiani merupakan manajemen yang didasarkan pada firman Tuhan sebagaimana tertulis dalam Alkitab. 
Kemudian Eims (1982, p. 164) menjelaskan dalam bukunya:

Yesus mempunyai kemampuan dalam pengelolaan. Ia dapat merangkai orang sedemikian rupa sehingga menjadi sebuah team. Dia adalah orang yang mengerti kebijakan sederhana bahwa dua orang dapat mencapai hasil yang baik daripada satu orang, jika mereka bersatu dan diorganisir. Ia tahu juga bahwa hal itu benar dengan tiga, empat orang atau lebih. Proyek yang bagaimana besarnya sekalipun dapat dibagibagi menjadi kesatuan kecil yang dapat berfungsi jika kita tahu cara mengaturnya.

Jadi, manajemen sangat diperlukan oleh seseorang pemimpin Kristen dalam kepemimpinannya pada masa kini. Dengan memahami manajemen yang baik maka akan berdampak pada proses dan hasil dari kepemimpinannya. Manajemen menjadi salah satu faktor pendukung penggembalaan yang efektif, karena dalam manajemen terdapat sebuah sistem dan fungsi yang baik. Karena pemimpin Kristen yang baik adalah pemimpin yang dapat memperkaya kepribadian orang yang dipimpinnya.

Berbagai masalah pemimpin maupun organisasi pada masa kini memerlukan kemampuan untuk mengelola dengan baik. Yesus telah memberi teladan, bagaimana mengelola pelayanan-Nya dengan baik dan hal itu tampak pada pemecahan masalah. Kemampuan manajemen ditambah dengan karakter yang baik seperti teladan Yesus menjadi modal penting untuk menjadi pemimpin.

\section{Pelayanan dalam Memimpin}

Prinsip kepemimpinan Kristen ialah memimpin dengan kasih, sehingga akan berdampak kepada kepemimpinan yang melayani atau menjadi pelayan. Hall (1992, p. 16) memaparkan bahwa pelayanan merupakan usaha untuk mempergunakan pengaruh dalam meningkatkan pertumbuhan rohani setiap orang yang dijumpai. Sebagaimana kembali diungkapkan oleh Engstrom dan Dayton (2007, p. 20) dalam bukunya bahwa, "Pemimpin Kristen sejati telah menemukan bahwa kepemimpinan dimulai dari handuk dan baskom-dalam peran seorang pelayan." Pendapat Engstrom dan Dayton merupakan teladan yang telah diberikan oleh Yesus. Yesus telah memberikan teladan bagi para murid untuk menjadi pelayan dengan menggunakan handuk dan baskom. Di tengah perubahan perilaku manusia serta kecenderungan manusia yang menuntut untuk dilayani atau pemimpin yang berperilaku seperti bos, teladan Yesus sebagai pemimpin yang efektif sangat relevan bagi pemimpin Kristen pada masa kini. Dari uraian di atas tampak bahwa sikap mau melayani orang yang dipimpin sangat diperlukan dalam kepemimpinan sehingga dapat mempengaruhi dan melayani orang lain. Santoso (2011, p. 74) memaparkan bahwa seorang pemimpin dalam mewujudkan kepemimpinannya bagi orang-orang yang dipimpinnya dan memberikan apa yang menjadi kebutuhan hidup orang yang dipimpin.

Dalam hal melayani, Yesus memberi teladan dengan melayani semua orang. Hal ini berbanding terbalik dengan pemimpin lainnya pada waktu itu yang cenderung hanya melayani kelompok tertentu. Teladan-Nya dalam melayani banyak orang menjadi modal penting untuk menjadi pemimpin yang efektif. Seorang pemimpin Kristen tidak dapat menjalankan kepemimpinannya hanya untuk memenuhi atau memuaskan kelompok tertentu, melainkan melayani semua orang sehingga terjadi kemajuan.

\section{KESIMPULAN}

Berdasarkan hasil analisis maka dapat dikemukakan beberapa keteladanan kepemimpinan Yesus, antara lain: Pertama, kerohanian Yesus dalam memimpin. Dalam hal kerohanian, Yesus adalah pemimpin yang tekun dalam berdoa, tekun membaca Kitab Suci, dan setia dalam memberitakan Injil. Kedua, keteladanan karakter Yesus dalam memimpin. Yesus adalah pemimpin yang menekankan serta menunjukkan kasih dalam memimpin, kemudian Ia memiliki sikap yang rendah hati sehingga Ia layak menjadi teladan. Yesus juga adalah pemimpin yang berintegritas sebagaimana ditunjukkan dalam Matius 22:15-22, Markus 12:13-17, dan Lukas 20:20-26. Yesus juga merupakan pemimpin yang berhati hamba, terbukti dari apa yang Yesus lakukan di mana Ia 
mengabdikan diri kepada Bapa, serta memberi diri untuk menjadi penebus. Ketiga, manajemen Yesus dalam memimpin. Sebagai pemimpin Yesus adalah pemimpin yang mendelegasikan tugas kepada para murid. Yesus menetapkan dua belas orang untuk menyertai Dia dan untuk diutus-Nya memberitakan Injil (Mat. 10:1-4, Mrk. 3:13-19, Luk. 6:12-16, dan Yoh. 35-51), kemudian Yesus memberi kuasa kepada kedua belas rasul untuk mengusir roh-roh jahat. Selain mendelegasikan tugas, penting bagi Yesus untuk melakukan evaluasi terhadap para murid. $\mathrm{Ke}$ empat, kompetensi Yesus. Sebagai seorang pemimpin yang baik, Yesus menjadi teladan sebagai seorang pemimpin yang melayani banyak orang. Pelayanan merupakan dasar kepemimpinan Yesus, sehingga dalam kepemimpinan-Nya lebih banyak waktu digunakan-Nya untuk bersama-sama dengan para murid dan orang banyak. Yesus juga pemimpin yang memberdayakan murid-murid, hal ini tampak dalam

\section{DAFTAR RUJUKAN}

Abineno, J.L. 1994. Doa Menurut Kesaksian Perjanjian Baru. Jakarta: Gunung Mulia.

Blanchard, K. \& Hodges, P. 2006. Lead Like Jesus. Tangerang: Visimedia.

Boice, J.M. 2015. Dasar-Dasar Iman Kristen. Surabaya: Momentum.

Brake, A. 2014. Spiritual Formation. Bandung: Kalam Hidup.

Coleman, R.E. 1963. Rencana Agung Penginjilan. Bandung: Kalam Hidup.

Darmawan, I P.A. 2017. "Murid yang Memuridkan", dalam I P.A. Darmawan, Melaksanakan Amanat Agung di Abad 21. Ungaran: Sekolah Tinggi Teologi Simpson.

Eims, L. 1982. Pemuridan Seni yang Hilang. Bandung: Literatur Baptis.

Engstrom, T.W. \& Dayton, E.R. 2007. Seni Manajemen bagi Pemimpin Kristen. Bandung: Kalam Hidup.

France, R.T. 1998. Yesus Sang Radikal. Jakarta: BPK Gunung Mulia.

Halim, M. 2003. Model-model Penginjilan Yesus. Malang: Gandum Mas.
Matius 4:19 di mana Yesus memahami konteks lawan bicara-Nya, sehingga dengan sengaja Yesus memberi sebuah tawaran, sehingga Simon dan Andreas pun mengikuti Yesus serta mengharapkan agar mereka yang telah dipilih-Nya dapat melayani. Selanjutnya, Yesus adalah pemimpin yang mampu menjadi teladan bagi para murid. Yesus dapat menjadi teladan dalam berapa yaitu berdoa (Mat. 26:36, Mrk. 14:32, Luk. 22:41-42, dan Yoh. 17:9) dan mengasihi orang-orang berdosa (Mat. 9:10, Mrk. 5:21, Luk. 8:40-46, dan Yoh. 3:16).

Implikasi keteladanan Yesus pada masa kini adalah pemimpin Kristen merupakan pemimpin yang berkarakter seperti Yesus yaitu memiliki kasih, kerendahan hati, berhati hamba. Kemudian pemimpin Kristen memiliki spiritualitas kepemimpinan yang baik, memiliki kemampuan manajemen dalam memimpin, dan menjadi pemimpin yang melayani semua orang.

Hall, B.P. 1992. Panggilan akan Pelayanan. Jakarta: Gunung Mulia.

Henrichsen, W.A. 1974. Cara Melatih Murid Kristus. Bandung: Kalam Hidup.

Henry, M. 2010. Tafsiran Matthew Henry: Injil Yohanes 12-21. Surabaya: Momentum.

Henry, M. 2011. Tafsiran Matthew Henry: Injil Markus. Surabaya: Momentum.

Iskandar, B.J. 2008. Management according to the Bible. Bandung: Kalam Indah Publishing.

Manullang, R.T. 2007. Leadership Reformation. Jakarta: Metanoia.

Mawikere, M.C. 2018. "Efektivitas, Efisiensi dan Kesehatan Hubungan Organisasi Pelayanan Dalam Kepemimpinan Kristen.” Evangelikal: Jurnal Teologi Injili dan Pembinaan Warga Jemaat, 2 (1): 50-67

Moore, W.B. 1981. Penggandaan Murid-Murid. Malang: Gandum Mas.

Morris, L. 2016. Tafsiran Injil Matius. Surabaya: Momentum.

Murray, A. 2001. Membina Iman. Bandung: Kalam Hidup. 
Nee, W. 2000. Pekerja Kristus. Bandung: Kalam Hidup.

Objantoro, E. 2017. "The Contextual Church Leadership", dalam I P.A. Darmawan, Melaksanakan Amanat Agung di Abad 21. Ungaran: Sekolah Tinggi Teologi Simpson.

Octavianus, P. 1988. Manajemen dan Kepemimpinan Kristen menurut Wahyu Allah. Malang: Gandum Mas.

Petterson, G. 2006. Pedoman Pelipat Gandaan Jemaat. Bandung: Kalam Hidup.

Price, J.M. 1975. Yesus Guru Agung. Bandung: Literatur Baptis.

Riggs, R.M. 1978. Gembala Sidang yang Berhasil. Malang: Gandum Mas.

Robinson, H.W. 2014. Mengambil Keputusan Sesuai Firman Tuhan. Jakarta: Duta Harapan Dunia.

Rush, M. 1993. Pemimpin Baru. Jakarta: Immanuel.

Sanders, J.O. 1962. Kedewasaan Rohani. Bandung: Kalam Hidup.

Sanders, J.O. 1979. Kepemimpinan Rohani. Bandung: Kalam Hidup.

Santoso, J. 2011. "Transformasi Kepemimpinan Yesus Terhadap Kepemimpinan Gembala Sidang dalam Mempersiapkan Pemimpin Masa Depan” Jurnal Jaffray, 9 (1).

Saragih, Jahenos. 2009. Manajemen Kepemimpinan Kristen. Jakarta: Suara Gereja Kristiani yang Esa

Sitompul, A.A. 1979. Di Pintu Gerbang Pembinaan Warga Gereja. Jakarta: BPK Gunung Mulia.

Soekahar, H. 1988. Bagaimana Memotivasi Jemaat Melayani. Malang: Gandum Mas.
Stalker, J. 1991. Masa Hidup Yesus Kristus. Malang: Gandum Mas.

Strom, M.B. 2004. Apakah Penggembalaan Itu? Jakarta: BPK Gunung Mulia.

Suwu, R. 2016. Suksesi Kepemimpinan Rohani Menurut Alkitab. Bandung: Kalam Hidup

Swindoll, C.R. 1985. Tanggalkan Topeng Anda. Surabaya: YAKIN.

Tanihardjo, B. 2015. Integritas. Yogyakarta: ANDI.

Thomas, M.W.I. 2000. Hidup Yesus dalam Hidupku. Bandung: Kalam Hidup.

Thomssoyan, Y.C. 2011 "Kepemimpinan Yesus Menurut Injil Sinoptik dan Relevansinya Terhadap Kepemimpinan Rohani Masa Kini”, Jurnal Jaffray, 9 (1).

Tomatala, Y. 1997. Kepemimpinan yang Dinamis. Malang: Gandum Mas.

Tong, S. \& Setiawani, M. 2003. Seni Membentuk Karakter Kristen. Jakarta: Lembaga Reformed Injili Indonesia.

Tong, S. 2001. Kerajaan Allah, Gereja dan Pelayanan. Surabaya: Momentum.

Walz, E. 2004. Bagaimana Mengelola Gereja Anda. Jakarta: BPK Gunung Mulia.

Whitney, D.S. 2007. Disiplin Rohani 10 Pilar Penopang Kehidupan Kristen. Bandung: Lembaga Literatur Baptis.

Wiersbe, W. \& Wiersbe, D.W. 2011. Rahasia Pelayanan. Yogyakarta: Andi.

Yeakley, T. 2013. Character Formation for Leaders. Bandung: Kalam Hidup. 